\section{The plasmatic index of body condition in Yellow-legged Gulls Larus cachinnans: a food-controlled experiment}

\author{
CARLOS ALONSO-ALVAREZ, ${ }^{1 *}$ \\ MIGUEL FERRER ${ }^{1}$ \& ALBERTO VELANDO ${ }^{2}$ \\ ${ }^{1}$ Department of Applied Biology, Estación \\ Biológica de Doñana, CSIC, Avda. Maria Luisa s/n, \\ 41013 Sevilla, Spain \\ ${ }^{2}$ Departamento de Ecoloxía e Bioloxía Animal, \\ Universidade de Vigo, 36200, Vigo, Spain
}

Over the last two decades, different methods of assessing body condition in birds have been developed to resolve ecological issues. Thus, plasma metabolites have been proposed as a method to assess body condition accurately (see review in Brown 1996). Jenni-Eiermann and Jenni (1994) related the individual change in body mass to the plasma concentration of different biochemical parameters in a food-controlled experiment in the Garden Warbler Sylvia borin aimed at finding a biochemical body condition index. In their study, birds were given a specific amount of food that induced the desired change in body mass. With the same aim, Williams et al. (1999) induced short-term fastings ( $24 \mathrm{~h}$ ) and refeedings in captive Western Sandpipers Calidris mauri. As far as we know, further research aimed at finding body condition indexes by relating body mass changes to biochemical parameters has not been carried out using food-controlled experiments.

The aim of our study was to develop a strong and reliable body condition index based on plasma biochemical parameters in the Yellow-legged Gull Larus cachinnans. This species is an opportunist feeder (Munilla 1997) and fluctuations in body condition may be related to changes in food supply or individual differences in feeding ability (e.g. Pierotti \& Annett 1991). Thus, a poor nutritional state could result from either under-feeding or a period of absolute fasting, so both situations were included in an experiment. We analysed 11 plasma parameters such as the total amount of protein, nitrogen waste (urea and uric acid), fats (such as triglycerides and cholesterol), carbohydrates (such as glucose), an enzyme (amylase) related to digestion (Duke 1986) and, lastly, creatinine and ions (related to muscular metabolism or kidney function; Brugère-Picoux et al. 1987).

*Corresponding author.

Email: alonso@ebd.csic.es

\section{METHODS}

In February 1999, 22 adult Yellow-legged Gulls were captured at a rubbish dump in Porriño, NW Spain $\left(42^{\circ} 09^{\prime} \mathrm{N}\right.$, $8^{\circ} 37^{\prime} \mathrm{W}$ ). The gulls were individually housed in cages and visually isolated with screens to avoid stress. The birds were divided into three groups, with a similar sex ratio (sex determined following Griffiths et al. 1998). Unlimited water was provided during the experiment. Nine individuals comprised the 'Fasting Group', nine the 'Underfed Group' and four birds formed the 'Control Group'. Sardines Sardina pilchardus are an important component of the diet of the original population (Munilla 1997). Thus, the gulls were fed ad libitum with sardines for 2 weeks before the experiment began, to avoid the effect of diet composition on plasma concentrations of various metabolites (e.g. Gavett \& Wakeley 1986). From the end of this 2week feeding period (day 0) onwards, food was withheld from the fasting group, the underfed group was fed only a third of its average daily intake (calculated on an individual basis during the previous 2 weeks), whilst the control group received food ad libitum. The end of the experiment was fixed $a$ priori at a loss of $20-25 \%$ of body mass with respect to the weight at day 0 . The number of days to reach this loss of body mass was found to vary greatly among individuals (fasting group: 8-12 days; underfed group: 10-18 days). The gulls were then re-fed and released at their original place of capture after resuming their initial weight. Total body mass loss (TBML) was defined as the proportion of body mass lost in relation to the highest body mass recorded during the study. For some individuals, this level corresponded to day 0 , while for others it corresponded to the moment of capture (body mass change from capture to day 0 : mean $=-3.0 \%$; range: $+6.5 \%$ to $-8.3 \% ; n=22$ ). There were no observed differences between the three groups for the above mentioned value (one-way ANOVA: $F_{2,21}=0.24 ; P=0.79$ ). The maximum body mass has been considered the individual's optimum value, and therefore we analysed an ideal range of individual body-mass change. Forced-feeding to attain higher weights was discarded, due to its stressful effect and the regurgitation capacity of this species.

Blood samples were taken from the humeral vein every 2 days from day 0 to the end of the experiment. Samples were taken at midday to avoid any variation related to circadian rhythms (e.g. García-Rodríguez et al. 1987a). The gulls were always weighed after blood sampling. The biochemical parameters of plasma were measured using a spectrophotometer (Hitachi 747, Tokyo, Japan) and commercial kits (Boehringer-Mannheim Biochemica, Mannheim, Germany). Triglyceride concentration analyses included free glycerol. Measurements were made in duplicate and repeatability was high (Lessells \& Boag 1987, $r>0.90$ in all parameters).

The use of biochemical variables as predictors of body condition was analysed using Generalized Linear Models 
Table 1. Generalized Linear Model results for the variables (plasma concentrations of biochemical parameters) that account for total body mass loss (TBML) in 18 Yellow-legged Gulls throughout the experiment. For each step, the change in deviance achieved by each explanatory variable and its significance when fitted into the model are shown. The variables were fixed in the model according to the degree of change in deviance, beginning with the highest, when the variables explained more than $5 \%$ of deviance. The total deviance in the null model after removal of the effects of individual birds was 4726.16; $d f=102$.

\begin{tabular}{lccc}
\hline \multicolumn{3}{c}{ Change in deviance } \\
\cline { 2 - 4 } & $\begin{array}{c}\text { Single } \\
\text { explanatory } \\
\text { variable }\end{array}$ & $\begin{array}{c}\text { Cholesterol } \\
\text { in the } \\
\text { model }\end{array}$ & $\begin{array}{c}\text { +Urea } \\
\text { in the } \\
\text { model }\end{array}$ \\
\hline Cholesterol & $3545.44^{* * *}$ & - & - \\
Urea & $2512.36^{* * *}$ & $218.72^{* * *}$ & - \\
Uric acid & $1465.15^{\star * *}$ & $70.95^{*}$ & 14.50 \\
Creatinine & $1464.44^{* * *}$ & $51.27^{*}$ & 12.84 \\
Glucose & $1462.02^{\star * * *}$ & 25.89 & $63.39^{*}$ \\
Calcium & $1231.54^{* * *}$ & 0.11 & 12.14 \\
Total protein & $1026.14^{\star *}$ & 19.86 & 0.53 \\
Inorganic phosphorus & $848.86^{* * *}$ & 0.73 & 0.71 \\
Triglycerides & $843.17^{* * *}$ & 13.46 & 1.97 \\
Amylase & $374.23^{* *}$ & 0.27 & 7.81 \\
Magnesium & 2.01 & 1.36 & 29.78 \\
\hline
\end{tabular}

${ }^{\star} P<0.05 ;{ }^{* \star} P<0.01 ;{ }^{* \star} P<0.001$.

(GLMs) with TBML as a dependent variable with normal error and identity link, using the GLIM package (Crawley 1993). Departure from a normal distribution was tested using the deviance of the null model. The statistical significance for differences among groups, for each variable, was tested in turn in the model (forward step-wise procedure, according to Bustamante 1997). The variables were accepted into the model when they explained more than $5 \%$ of deviance. As a first step, a group factor (fasting or underfed) was fixed in the models. During the experiment, the gulls in the control group showed no significant variations either in TBML or in plasma biochemical parameters (repeatedmeasures ANOVA: $P>0.05$ in all cases). We only considered the control group as a calibrator of protocol suitability. In order to avoid pseudoreplication caused by the use of data from the same bird, we included bird identity as a set of 17 dummy variables. Then, statistics were calculated on the within-bird deviance. Product-moment correlation coefficients were calculated following Crawley (1993, page 102).

\section{RESULTS}

On the first day, no differences were found between groups or sexes for any of the parameters (one-way ANOVA: $P>$ 0.1 ; in both cases). In the GLM test, the factor group was non-significant. Bird identity explained $14 \%$ of the deviance in the model. The TBML correlated significantly with 10 single variables (Table 1), although only five accounted

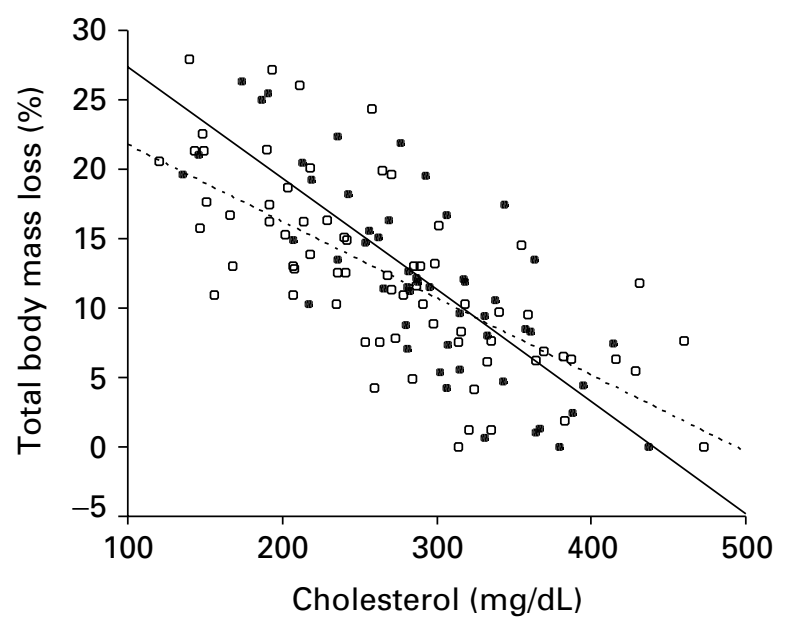

Figure 1. Relationship between the plasma cholesterol concentration and the proportion of total body-mass loss in 18 foodcontrolled Yellow-legged Gulls. Solid circles are data from the fasting group and open circles from the underfed group. Continuous and dotted lines adjusted to linear regression data correspond to the fasting and underfed groups, respectively. (TBML $=6.064+$ 205.110 Cholesterol). Pseudoreplication was controlled by including a set of 17 dummy variables (see statistics in methods).

for more than $30 \%$ of the deviance in the null model: cholesterol $(r=-0.87)$, urea $(r=0.73)$, uric acid $(r=0.56)$, creatinine $(r=-0.56)$ and glucose $(r=-0.56)$. Cholesterol and urea accounted for $75 \%$ and $53 \%$ of the deviance, respectively. The final model, including cholesterol and urea as explanatory variables, accounted for $80 \%$ of deviance (Table 1).

\section{Discussion}

The aim of this study was to find an index of body condition in Yellow-legged Gulls that could be used as a tool in future research. Plasma cholesterol was the single variable that best reflected body mass change (Fig. 1). Furthermore, the experimental group (fasting or underfed) was not found to affect the models. The decrease in cholesterol might be explained by the diminution of the anabolic processes. This lipid is involved in the formation of cellular membranes, steroids and bile acids (Griminger 1986). Unlike our results, cholesterol was shown to be stable during a study of absolute fasting in Herring Gulls Larus argentatus (Totzke et al. 1999). However, the diet and age composition of the gulls used in that study greatly differed from our experiment. Totzke et al. (1999) indiscriminately used yearlings and adult gulls, and fed them with commercial chicken food, rather than fish. Averbeck (1992) observed cholesterol level increase with age in freeliving Herring Gulls, and the proportion of fish taken is very important in the gull life history, since it affects breeding life-span and reproductive performance (Annett \& Pierotti 1999). Averbeck (1992) also suggested an influence 
of diet composition on cholesterol values for gulls (also see review about diet influence on cholesterol level for birds in Griminger 1986). The initial cholesterol concentration in the present study was found to be higher (mean: $8.72 \mathrm{mmol} / \mathrm{L}$; SE: \pm 0.47 ) than in Totzke's study. Therefore, an initial low level of plasma cholesterol could lower the possibility of further reduction during fasting. Cholesterol levels at the beginning of our experiment were similar to levels found in free-living individuals. Moreover, we found a significant positive correlation (Pearson coefficient: $r=0.69$ ) between cholesterol plasma concentrations and mass changes in 17 adult Yellow-legged Gulls captured and recaptured during incubation (C. AlonsoAlvarez unpubl. data). Thus, the method described here would work well for free-living individuals.

The increase in protein catabolism products (urea and uric acid) could be explained by the use of proteins as an energy source (Castellini \& Rea 1992). This increment has been observed in many species during fasting experiments (e.g. García-Rodríguez et al. 1987b, Sartori et al. 1995). These variables were used as an index of body condition in raptors (e.g. Ferrer 1992). The proportion of deviance explained by the model was increased by the inclusion of urea. However, the small difference between the use of cholesterol and the use of both parameters (5\% of deviance) has led us to propose the former as the simplest body condition index. Moreover, nitrogen wastes can be derived from food protein (e.g. Okumura \& Tasaki 1969). We could expect a range of protein richness in the gull diet in the field. Thus, a bird with a rich protein diet could mistakenly be taken as having a poor body condition by considering plasma urea values.

To conclude, cholesterol concentration in plasma should be used to reveal relative differences in one sample in the field rather than to estimate the absolute change in body mass by means of the regression equation (Fig. 1). We consider that mass change is a better predictor of body condition than the time period without food, due to the extremely variable effect of the latter in body mass among individuals. The cholesterol index must be applied preferably to adults, since this parameter could show different trends during food restriction in young birds (see Averbeck 1992).

We are grateful to J.L. Tella, A. Green and J. Figuerola for their valuable comments. Thanks are also due to an anonymous referee for comments on the first version of this manuscript.

\section{REFERENCES}

Annett, C.A. \& Pierotti, R. 1999. Long-term reproductive output in western gulls: consequences of alternative tactics in diet choice. Ecology 80: 73-82.

Averbeck, C. 1992. Haemathology and blood chemistry of healthy and clinically abnormal Great Black-backed Gulls (Larus marinus) and Herring Gulls (Larus argentatus). Avian Pathol. 21: 215-223.
Brown, M.E. 1996. Assessing body condition in birds. In Nolan, V. \& Ketterson, E.D. (eds) Current Ornithology, Vol. 13: 67-135. New York: Plenum Press.

Brugère-Picoux, J., Brugère, H., Basset, I., Sayad, N., Vaast, J. \& Michaux, J.M. 1987. Biochimie Clinique en pathologie aviaire. Introit et limites des dosages enzymatiques chez la Poule. Rcl. Méd. Vét. 163: 1091-1099.

Bustamante, J. 1997. Predictive models for lesser kestrel Falco naumanni distribution, abundance and extinction in southern Spain. Biol. Conserv. 80: 153-160.

Castellini, M.A. \& Rea, L.D. 1992. The biochemistry of natural fasting at its limits. Experientia 48: 575-582.

Crawley, M.J. 1993. GLIM for Ecologists. Oxford: Blackwell Scientific Publications.

Duke, G.E. 1986. Alimentary canal: secretion and digestion, special digestive functions, and absorption. In Sturkie, P.D. (ed.) Avian Physiology: 289-302. New York: Springer-Verlag.

Ferrer, M. 1992. Regulation of the period of postfledging dependence in the Spanish Imperial Eagle Aquila adalberti. Ibis 134: 128-133.

García-Rodríguez, T., Ferrer, M., Carrillo, J.C. \& Castroviejo, J. 1987b. Metabolic responses of Buteo buteo to long-term fasting and refeeding. Comp. Biochem. Physiol. 87A: 381-386.

García-Rodríguez, T., Ferrer, M., Recio, F. \& Castroviejo, J. 1987a. Circadian rhythms of determined blood chemistry values in buzzards and eagle owls. Comp. Biochem. Physiol. 88A: 663-669.

Gavett, A.P. \& Wakeley, J.S. 1986. Blood constituents and their relation to diet in urban and rural House Sparrows. Condor 88: 279-284.

Griffiths, R., Double, M.C., Orr, K. \& Dawson, R.J.G. 1998. A DNA test to sex most birds. Mol. Ecol. 7: 1071-1075.

Griminger, P. 1986. Lipid metabolism. In Sturkie, P.D. (ed.) Avian Physiology: 345-358. New York: Springer-Verlag.

Jenni-Eiermann, S. \& Jenni, L. 1994. Plasma metabolite levels predict individual body mass changes in a small long-distance migrant, the Garden Warbler. Auk 111: 888-899.

Lessells, C.M. \& Boag, P.T. 1987. Unrepeatable repeatabilities: a common mistake. Auk 104: 116-121.

Munilla, I. 1997. Estudio de la población y ecología trófica de la gaviota patiamarilla (Larus cachinnans) en Galicia. PhD Thesis, University of Santiago de Compostela.

Okumura, J. \& Tasaki, I. 1969. Effect of fasting, refeeding and dietary protein level on uric acid and ammonia content of blood, liver and kidney in chickens. J. Nutr. 97:316-320.

Pierotti, R. \& Annett, C.A. 1991. Diet choice in the herring gull: constraints imposed by reproductive and ecological factors. Ecology 72: 319-328.

Sartori, D.R.S., Migliorini, R.H., Veiga, J.A.S., Moura, J.L., Kettelhut, I.C. \& Linder, C. 1995. Metabolic adaptations induced by long term fasting in quails. Comp. Biochem. Physiol. 111A: 487-493.

Totzke, U., Fenske, M., Hüppop, O., Raabe, H. \& Schach, N. 1999. The influence of fasting on blood and plasma composition of Herring Gulls (Larus argentatus). Physiol. Zool. 72: 426-437.

Williams, T.D., Guglielmo, C.G., Egeler, O. \& Martyniuk, C.J. 1999. Plasma lipid metabolites provide information on mass change over several days in captive Western Sandpipers. Auk 116: 994-1000. 